\title{
Effects of Solid Wastes on the Quality of Selected Well Water in Odo-Oro Area of Ikere, Ekiti in Nigeria
}

\author{
Alonge, T. $\mathrm{O}^{1} \quad$ Adaramodu, A. A ${ }^{2} \quad$ Adegboye, A.D ${ }^{3}$ \\ 1.Department of Integrated Science, College of Education, Ikere Ekiti, Ekiti State, Nigeria \\ 2.Department of Chemistry, College of Education, Ikere Ekiti, Ekiti State, Nigeria \\ 3.Department of Biology College of Education, Ikere Ekiti, Ekiti State, Nigeria
}

\begin{abstract}
This paper presents an assessment of the impact of uncontrolled and unscientific disposal of Solid waste on ground water in Ikere Ekiti town, Nigeria. In this study, well water quality around solid waste dumpsite sites was investigated. Ground water quality analysis was carried out on water samples collected from four wells labelled 1 to 4 close to solid waste disposal sites. Physico-chemical parameters of the water samples (such as temperature, $\mathrm{pH}$, conductivity, dissolved oxygen, $\mathrm{BOD}, \mathrm{COD}$, turbidity, total dissolved solids, total suspended solids, total hardness, phosphates, sulphates, chlorides and nitrates) were measured. Results of analysis across the four samples gave a temperature range of $28^{\circ} \mathrm{C}-32.0^{\circ} \mathrm{C}, \mathrm{pH} 7.26-7.75$, conductivity $393.0-416.0 \mu \mathrm{m} / \mathrm{cm}, \mathrm{BOD} 4.0-4.5 \mathrm{mg} / \mathrm{l}$, DO 7.5 - $9.9 \mathrm{mg} / \mathrm{l}, \mathrm{COD} 4.0-70.0 \mathrm{mg} / \mathrm{l}$, phosphates, sulphates, chlorides and nitrates $0.17-0.30 \mathrm{mg} / 1,10.1-25.0$ $\mathrm{mg} / 1,3.7-11.5 \mathrm{mg} / \mathrm{l}$, and $0.113-0.22 \mathrm{mg} / \mathrm{l}$ respectively, total hardness 32.2 and $38.1 \mathrm{mg} / \mathrm{l}$. evidences from the above measurements showed a substantial level of contamination across all samples of water. Based on these outcomes it was recommended that wells should be sited at least $30 \mathrm{~m}$ from solid wastes dump site, Appropriate place should be located at the outskirt of the town for refuse / disposal, the wells should be treated at least three times in a year, the regulatory agency should employ a geologist on its staff list, preferably one trained in the area of hydrogeology, to assist in solid wastes site selection within the states, the use of groundwater monitoring wells should be considered in those areas where some doubts exist as to future effects of a particular solid wastes operation, the regulatory agency should not discourage novel methods of collecting and treating refuse leachates for certain installations where proper monitoring can be exercised.
\end{abstract}

Keywords: Solid Waste, Well Water, Ground water, Dump Site, Physico-chemical,

DOI: $10.7176 / \mathrm{JEES} / 10-7-05$

Publication date:July $31^{\text {st }} 2020$

\section{Introduction}

The problem of solid wastes disposal and its effect on the quality of underground water has always gained attention the world over. Merriam Webster (2001) defines waste as "refuse from places of human or animal habitation. Solid wastes could be defined as non-liquid and non gaseous products of human activities, regarded as being useless. It could take the forms of refuse, garbage and sludge (Leton and Omotosho, 2004). Developed nations boast of an organized and well engineered system of waste management which minimizes the health risk posed by waste pollution on their immediate environment (Mor et al., 2006). This is in sharp contrast to what is obtainable in developing nations like Nigeria where illiteracy, inadequate waste disposal system and awareness education, lack of capital, lack of requisite technology for environmentally friendly waste management practices and absence of political will from government and has left most places in Nigeria to rely on landfills for solid waste disposal. In most cases, wastes from these areas are not properly managed and engineered, which leads to environmental pollution.

Municipal solid waste generation can be influenced by several factors such as economic development, income level, industrialization, urbanization, human attitude and local climatic conditions (Odoemene, 2006). Records have shown that in Nigeria, the average waste generation rate is about $0.58 \mathrm{~kg} /$ person/day which is much lower compared to developed countries (Sridhar \& Adeoye, 2003).

Reports have shown that the quantity and the rate of solid wastes generation in Nigeria have outgrown the capacity of nature to naturally absorb them (Babayemi \& Dauda, 2009). Hence, every individual in the country and more importantly the government has a part to play in ensuring proper waste management. Ukem (2008) have observed that little or no attention is given to some traditional suburban settlements (like - Ikere Ekiti) for provision of waste collection and disposal services.

The common practice of waste management in Ikere Ekiti - a city in western Nigeria, is land filling or opendumping often as a result of its relatively cheaper cost (Olowe et al, 2015). Some of the open dumps are indiscriminately located at streams, valleys, water lands, open fields and abandoned borrow-pits. This system of waste disposal accumulates huge quantity of waste annually and is associated with several problems such as contamination of groundwater and outbreak of various human diseases. Wastes of different types, mostly solid wastes are the major input of dumpsites/landfills.

Improper disposal of these untreated wastes can be deleterious. Air pollution, underground water 
contamination, land degradation, soil contamination and habitat deterioration can be caused by improper waste disposal. For example, environments close to dumpsites are constantly exposed to risk of infection due to groundwater contamination and exposure to hazardous compounds (Ukponh \& Udo, 2015, Ayuba et al, 2013).

Water is critical to our daily lives and is an extraordinary compound in nature. It covers $71 \%$ of Earth (USGS, 2014). Water is the most important resource of a country, and of the entire society, since no life is possible without water. Groundwater forms that part of the natural water cycle present within underground strata or aquifers. Of the global quantity of available freshwater, more than $98 \%$ is groundwater stored in pores and fractures of rock strata. Groundwater is a significant part of the hydrologic cycle, containing 21 percent of Earth's freshwater and it serves domestic, industrial and agricultural purposes. Groundwater is assessed through wells or boreholes which are used for drinking and other domestic purposes.

Lack of municipal water supply, rapid and unplanned urbanization, and the relatively cheaper cost of accessing groundwater make it a favourable choice for households in Nigeria. Groundwater usage cuts across various sectors, accounting for $42 \%$ agricultural, $36 \%$ domestic, and $27 \%$ industrial purposes in Nigeria; hence, it remains a vital resource (Olusola et al. 2017). It is accessed either as shallow, hand-dug wells, or as deep, borehole wells (Omole 2013). Given its abundance and relatively cheaper cost of development (Soladoye and Ajibade 2014), virtually every household in urban cities in Nigeria owns private hand-dug water wells to make up for lack of municipal water supply.

Closeness of dumpsites to ground water sources such as well water had been reported to impact the quality of ground water through underground leaching or surface run-offs. A number of incidences have been reported in the past, where leachate had contaminated the surrounding soil and polluted the underlying ground water aquifer or nearby surface water (Gopal et al., 1991; Olaniyan et al., 1998; Kumaraswamy et al., 2000; Mor et al., 2006; Vasanthi et al., 2008). Such contamination occur through leakage; which is formed when rain water infiltrates the landfill and dissolves the solute fraction of the waste and the soluble product formed as a result of the chemical and biochemical processes occurring within the decaying wastes. The resultant effluent will however impose their Chemical Oxygen Demand (COD) and Biochemical Oxygen Demand (BOD) on the ground water. Recent studies have shown that the COD and BOD of such wastes may be in the region at $12,000 \mathrm{mg} / \mathrm{L}$ and $700 \mathrm{mg} / \mathrm{L}$ respectively with the concentration of inorganic chemical substances like ammonia, iron and manganese varying according to the hydrology of the site and chemical and physical conditions within the site. Even if there are no hazardous wastes placed in municipal landfills, the leachate is still reported as a significant threat to the groundwater (Lee, 2002).

Studies have shown that lack of adequate monitoring by appropriate agencies has resulted in cases of reported microbial contamination of drinking water in various states in Nigeria (Adekunle et al. 2007). As noted by Olowe et al. (2015), reports of microbial contamination of drinking water sources, which links to a lack of public water system (potable water) and inadequate groundwater monitoring, have resulted in high rates of water-borne diseases such as cholera, typhoid fever, dysentery, and diarrhoea.

Groundwater vulnerability is made evident by studies conducted in Ado-Ekiti, Southwestern-Nigeria by Olowe et al. (2015), where 300 samples of groundwater wells and boreholes were assayed for microbial parameters. About $37 \%$ of these samples tested positive for Escherichia coli (E. coli). In another study, Weli and Ogbonna (2015) reported water-borne diseases associated with groundwater in Emohua - a rural community of Rivers state, Southern Nigeria. As reported by Weli and Ogbonna (2015), the prevalence of these diseases has affected the economy of the local inhabitants. On an individual basis, it comes with a considerable cost and financial burden which includes medications and medical treatment costs among others.

A 1999-2001 study by Adelana et al. (2005) showed contaminants were associated with anthropogenic activities mainly due to the shallow depth of the Lagos aquifer. Eni et al. (2011) also affirmed the effect of urbanization on groundwater quality. The assessment of groundwater in Calabar, South-Southern Nigeria, revealed acidity, nitrate, and faecal coliform contamination. Another study by Amadi et al. (2010) showed water samples close to the dumpsite, in Makurdi, North-central Nigeria, exhibit low $\mathrm{pH}$, high content of total dissolved solids (TDS), iron (Fe), manganese (Mn), calcium (Ca), and coliform - linked with poor waste management — compared to samples farther from dumpsite.

Following this backdrop, this study investigates the effects of solid wastes on the quality of selected well water in Odo-Oro area of Ikere, Ekiti in Nigeria with the aim of providing ideological method, improvement and solution in the area on the effect of solid wastes on underground water in the area.

Objectives

The aim of this research is to measure the physicho-chemical parameters of selected well water samples in Odo Oro area of Ikere-Ekiti, Nigeria.

Materials and Methods

Study area

Ekiti is one of the 36 states in Nigeria while Ikere is a City in Ekiti State, which is found in the South West region of Nigeria. Ikere Ekiti is found on the following coordinates: latitude - $7^{\circ} 29^{\prime} 50.93^{\prime \prime} \mathrm{N}$ and longitude $-5^{\circ} 13^{\prime}$ 
49.48" E. Odo-Oro (the study location) is a town in Ikere Ekiti which is not only a residential area for indigenes of the town but also a town of residence for students of the College of Education Ikere Ekiti who have travelled far and wide to School in this area.

\section{Sample collection, Preservation and Analysis}

Four wells samples were randomly picked within the study area of the dump site. All samples were collected same day and kept in two litres rubbers bottles, which were washed with $10 \% \mathrm{HNO}_{3}$ and $1.1 \mathrm{HCl}$ for $48 \mathrm{hrs}$. The rubber bottles were labeled and immediately few drops of $\mathrm{HNO}_{3}$ was added in order to prevent loss of metals, bacterial and fungal growths. Temperature, turbidity and $\mathrm{pH}$ of water samples were also measured at the time of collection. The four well water samples were analyzed using various standard procedures for thirteen parameters: $\mathrm{pH}$, conductivity, turbidity, temperature, alkalinity, total suspended solids, total hardness, chlorides, phosphate, nitrates, lead, Biochemical oxygen demand, and faecal coliform count. The procedure was adopted for the determination of these physicochemical parameters.

Results and Discussion

The mean values of the physicochemical parameters of the four different well waters samples in Odo Oro area of Ikere Ekiti State are reported in the table below and discussed afterwards.

Table 1: Physico-Chemical Parameter Results of Samples from the four well in Ikere

\begin{tabular}{|llllll|}
\hline PARAMETER & WELL & WELL & WELL & WELL & WHO \\
& $\mathbf{1}$ & $\mathbf{2}$ & $\mathbf{3}$ & $\mathbf{4}$ & Standard \\
Temperature ${ }^{\circ} \mathrm{C}$ & 29.5 & 32.0 & 28.0 & 31.0 & 35.40 \\
PH & 7.26 & 7.75 & 7.34 & 7.75 & 65.85 \\
Coductivity (mg/l) & 393.0 & 416.0 & 356.0 & 412.0 & 1000 \\
Biochemical Oxygen Demand & 4.5 & 49.5 & 4.0 & 43.5 & \\
(BOD) (mg/) & & & & & \\
Dissolved Oxygen (mg/1) & 8.5 & 7.6 & 9.9 & 7.5 & 2.0 \\
Phosphate (mg/1) & 0.17 & 0.29 & 0.19 & 0.30 & 5.0 \\
Sulphate (mg/l) & 10.1 & 26.8 & 11.1 & 25.0 & 250 \\
Chloride (mg/l) & 5.7 & 11.5 & 3.7 & 10.0 & 250 \\
Nitratc (mg/l) & 0.115 & 0.21 & 0.113 & 0.22 & 10 \\
Total Hardness (mg/1) & 34.9 & 38.1 & 32.2 & 37.1 & 100 \\
Turbidity NTU (mg/1) & 32.0 & 59.0 & 31.0 & 60.0 & 5 \\
Total Suspended Solid (mg/l) & 530 & 760 & 490 & 710 & 30 \\
Total Solid (mg/l) & 560 & 790 & 300 & 700 & \\
Chemical Oxygen Demand & 4.0 & 70.0 & 5.0 & 65.0 & \\
(COD) (mg/1) & & & & & \\
\hline
\end{tabular}

From the result obtained above, the following deductions were made with respect to the various physicochemical properties measured:

\section{Temperature}

The temperature of the samples ranges between $28^{\circ} \mathrm{C}$ and $32.0^{\circ} \mathrm{C}$. Well 3 had the lowest temperature $28^{\circ} \mathrm{C}$ while well 2 had the highest temperature $32^{\circ} \mathrm{C}$. These ranges were higher than the WHO limit of $25^{\circ} \mathrm{C}$. However, these values were close to those obtained by Nwosu et al., (2014) and Siyanbola et al., (2011), who recorded a mean temperature of 31 and a range of 28.00 and 35.35 , in separate studies. The temperature recorded in this study favours increased rate of chemical and biochemical reactions, the solubility of gases in water, which could impart negatively on the taste and odour of the water at higher temperatures

pH

$\mathrm{pH}$ value ranges between 7.26 and 7.75. These results were within the range of 6-9 $\mathrm{pH}$ range for WHO (2010) and FEPA (1991) and close to the value recorded by Onwordi et al., (2010) but higher than those recorded by Siyanbola et al., (2011). It should be noted that high $\mathrm{pH}$ increases the toxicity of ammonia while low $\mathrm{pH}$ increases the toxicity of $\mathrm{H}_{2} \mathrm{~S}$ and cyanide in water. Changes in $\mathrm{pH}$ are known to be as a result of processes such photosynthesis, respiration, exposure to air, disposal of industrial wastes, geology and mineral content of a catchment area, accumulation and decomposition or leaching or organic debris producing chemicals that impart on the $\mathrm{pH}$ (Bisi- 
Johnson, 2017).

Conductivity

The mean conductivity values of the water samples ranges between 393.0 and $416.0 \mu \mathrm{m} / \mathrm{cm}$. The values were below the WHO limit (2007) of $1000 \mu \mathrm{m} / \mathrm{cm}$ but above the range recorded by Onwordi et al., (2010) 79.37 and $244.92 \mu \mathrm{m} / \mathrm{cm}$. The higher conductivity recorded may be due to the presence of highly soluble dissolved solids especially salts of sodium and potassium washed into the river. The overall chemical richness of any water is a reflection of its conductivity values. The relatively low conductivity values compared to the WHO and NSDWQ standards may be attributed to lower concentrations of chlorides, sulphates and TDS which are indicators of lower salt content. The conductivity of water is a useful and assessable indicator of salinity or its total salt content (Oluyemi, 2010).

Biochemical Oxygen Demand (BOD).

Biochemical oxygen demand measures the amount of oxygen used by micro-organisms. The BOD values of well 1 and 3 ranges between 4.0 and $4.5 \mathrm{mg} / 1$ and found to be within the acceptable WHO limit of $6 \mathrm{mg} / \mathrm{L}$. Hence, Water from well 1 and 3 could be judged comparatively clean by WHO (2010) acceptable standard. The values recorded for well 2 and 4 were 49.5 and $43.5 \mathrm{mg} / 1$ respectively which are found to be far above $6 \mathrm{mg} / 1 \mathrm{standard}$ for WHO (2010). The high value of BOD for the well water 2 and 4 corroborates the relatively high temperature recorded which might have lead to microbial activities within the water. This on the other hand may have been due to heavy leaching of waste pollutant from the dumpsite close-by into well water 2 and 4.

\section{Dissolved Oxygen}

The dissolved oxygen values ranges between 7.5 and $9.9 \mathrm{mg} / \mathrm{l}$. The values are fairly higher than the acceptable minimum of $2 \mathrm{mg} / 1$ standard for WHO (2010). These values were lower to those recorded by Segun et al., (2017) which ranges between 5.07 and $14.56 \mathrm{mg} / \mathrm{l}$. DO is an essential measure of the extent of pollution; the lower its value, the higher the pollution and vice versa (Mgbemena, 2014). Portable water should contain at least $5 \mathrm{mg} / 1$ (Obodo, 2002). Although its serves as an indicator of the biological health of a water body, nevertheless, its level can fluctuate throughout the day and are affected by changes in water temperature and the concentration of organic material (industrial and municipal wastes can increase the concentration of organic matter) (USEPA, 1997).

\section{Phosphate, Sulphate, Chloride and Nitrates}

The concentrations of ions such as phosphate, sulphate, chloride and nitrate in the water samples were within the range $0.17-0.30 \mathrm{mg} / 1,10.1-25.0 \mathrm{mg} / 1,3.7-11.5 \mathrm{mg} / \mathrm{l}$, and $0.113-0.22 \mathrm{mg} / \mathrm{l}$ respectively. All these ions fall within the permissible WHO (2010) and FEPA (1991) standards, as such their presence may pose no health risk to consumers. This may the reason for the relatively low electrical conductivity recorded in the water samples. The value of phosphate concentration were found to be lower than those recorded by Onwordi et al., (2010) which ranges between 3.13 and $3.46 \mathrm{mg} / 1$. The value of sulphate recorded were similar to those recorded by Onwordi et al., (2010) and Siyanbola et al., (2011) but lower than those recorded by Ani et al., (2011) which ranges between 951.00 and $952.20 \mathrm{mg} / \mathrm{l}$.

\section{Total Hardness}

Water hardness is occasioned by the presence of carbonates and bi-carbonates of calcium and magnesium. The results show that total hardness ranges between 32.2 and $38.1 \mathrm{mg} / 1$. These values are below the WHO (1993) limit of $500 \mathrm{mg} / \mathrm{l}$. These values were fairly similar to those recorded by Segun et al., (2010) and Onwordi et al., (2010) but lower than the value recorded by Ani et al., (2011). The relative low concentrations as recorded were indications of low carbonates and bicarbonates of calcium and magnesium in the well water samples.

Turbidity

The results show that the turbidity ranges between 31.0 and $60.0 \mathrm{mg} / \mathrm{l}$. These values were similar to this obtained by Segun et al., (2010). The values were also extremely greater than the WHO recommended guideline value of 5 NTU mg/l. Turbidity levels are dependent on the amount of suspended particles in the water which. Suspended particles act as a substrate for micro organisms in water, thus promoting growth of the microbial population. Hence, the higher the turbidity level, the higher the risk of promoting disease causing organisms in water.

\section{Total Dissolved Solid (TDS)}

The results show that TDS ranges between 65.0 and $95.0 \mathrm{mg} / \mathrm{l}$. These values were within the WHO and FME recommended limit of $500 \mathrm{mg} / \mathrm{l}$. The value obtained was also similar to those obtained by Onwordi et al., (2010) and Siyanbola et al., (2011).

\section{Total Suspended Solid (TSS)}

The results show that TSS ranges between 490 and $710 \mathrm{mg} / \mathrm{l}$. These values were far above the WHO and FME recommended limit of $30 \mathrm{mg} / \mathrm{l}$. The value obtained was fairly similar to those recorded by Onwordi et al., (2010). This could be an indication of the dirty nature of the water. The very high value of total suspended solids might have been responsible for the high turbidity value recorded across the well water samples.

\section{Total Solid}

The total solids of the underground water represent its dry matter content. It is the sum of the total dissolved solids and total suspended solids in the underground water (Chukwu, 2008). The total solids obtained were within WHO 
limit of $2030 \mathrm{mg} / \mathrm{l}$. The value obtained was higher than those recorded Onwordi et al., and Siyanbola et al., (2011) bit lower than the value recorded by Segun et al., (2010).

\section{Chemical Oxygen Demand (COD)}

The COD values obtained from the water samples ranges between 4.0 and $70.0 \mathrm{mg} / \mathrm{l}$. The values were within the WHO (2010) recommended value of $90 \mathrm{mg} / \mathrm{l}$. The well 2 value closed to those between recorded by Segun et al., (2010) which ranges between (50-175 mg/l) but below the value between 96.00 and $272.50 \mathrm{mg} / 1 \mathrm{recorded}$ by Onwordi et al., (2010). The high concentration of the well may be due to flow of waste into the water from the dumping site. These values were similar to those obtained by Siyanbola et al., (2011). The high value may be due to the inflow of water armed with debris and other organic matter into the well or a high amount of waste from the nearby dumping sites flowing into the well.

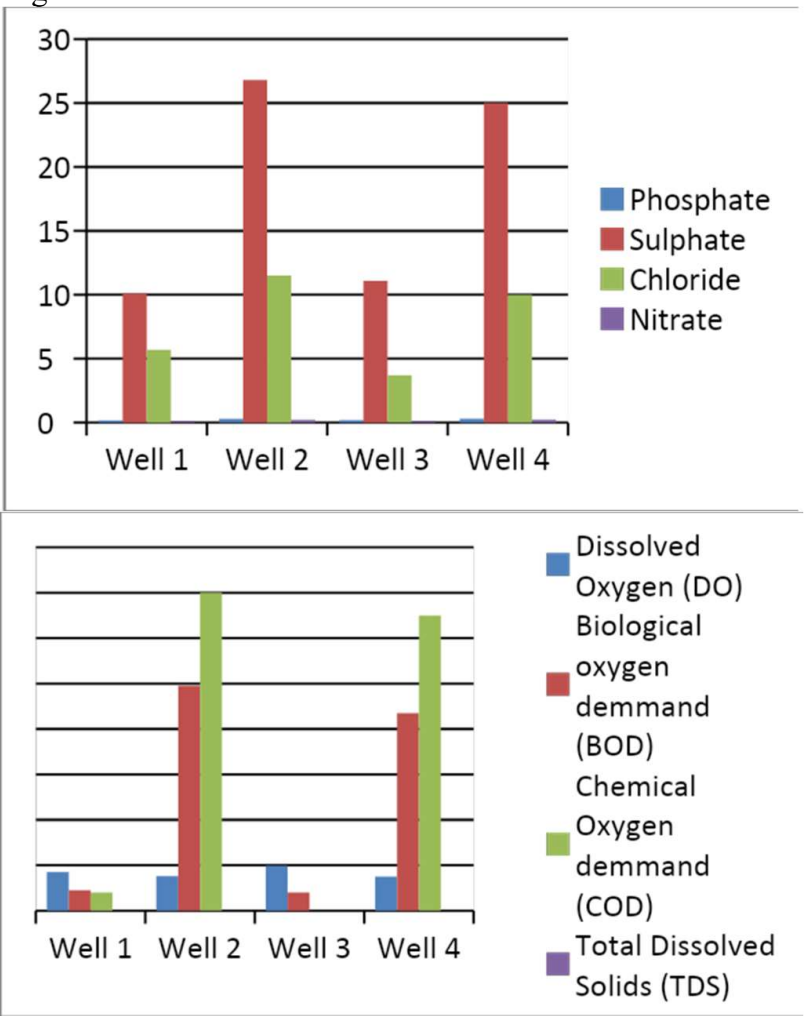

Conclusion

From the results of the tests

Result of physico-chemical parameter measurements showed levels of contamination across the four well waters which make it unsafe for drinking.

\section{Recommendations}

From the above findings on the effect of solid wastes on underground water, the following recommendations were made:

- The wells should be sited at least $30 \mathrm{~m}$ from solid wastes dump site.

- Appropriate place should be located at the outskirt of the town for refuse / disposal

- The wells should be treated at least three times in a year.

- The regulatory agency should employ a geologist on its staff list, preferably one trained in the area of hydrogeology, to assist in solid wastes site selection within the states.

- The use of groundwater monitoring wells should be considered in those areas where some doubts exist as to future effects of a particular solid wastes operation.

- The regulatory agency should not discourage novel methods of collecting and treating refuse leachates for certain installations where proper monitoring can be exercised.

- The regulatory agency should encourage the practice of regional or district approaches to solid waste collection and disposal. Economic incentives should be available to provide funds to make area-wide feasibility studies. This approach will reap great benefits in the control of solid waste disposal practices.

- Federal, state and local government should take several steps to monitor and control waste disposal. Practical effort should also be made by the government, industrial sector and the public towards minimizing environmental pollution. 


\section{References}

Adekunle, I.M, Adetunji, M.T, Gbadebo A.M, Banjoko, O.B. (2007). Assessment of groundwater quality in a typical rural settlement in southwest Nigeria. Int J Environ Res Public Health 4(4):307-318

Adelana, S.M.A, Bale, R.B, Olasehinde, P.I, Wu, M. (2005). The impact of anthropogenic activities over groundwater quality of a coastal aquifer in southwestern Nigeria. In: Aquifer vulnerability and risk, 2nd international workshop, 4th congress on the protection and management of groundwater, 21-23 September 2005. Reggia di Colorno, Parma, pp 1-11

Amadi, A.N, Ameh, M.I, \& Jisa J (2010). The impact of dump sites on groundwater quality in Markurdi Metropolis, Benue State. Nat App Sci J 11(1):90-102

Ayuba KA, Manaf LA, Sabrina, A.H, \& Azmin, S.W.N. (2013). Current status of municipal solid waste management practise in FCT Abuja. Res. J. Environ. Earth Sci. 5:295-304.

Babayemi, J. O., 2 Dauda, K. T (2009). Evaluation of Solid Waste Generation, Categories and Disposal Options in Developing Countries: A Case Study of Nigeria. J. Appl. Sci. Environ. Manage. 13(3): 83 - 88

Bisi-Johnson M. A, Adeniran K. O, Akinola S. A, Popoopa E. O, \& Okoh A. I (2017). Comparative Physicochemical and Microbiological Qualities of Source and Stored Household Waters in Some Selected Communities in Southwestern Nigeria. Sustainability journal. 9, 454; doi:10.3390/su9030454. www.mdpi.com/journal/sustainability.

Eni DV, Obiefuna J, Oko C, \& Ekwok I (2011) Impact of urbanization on sub-surface water quality in Calabar municipality, Nigeria. Int J Humanit Soc Sci 1(10):167-172

Gopal D., Singh R.P. \& Kapoor R.C. (1991), Ground water pollution by solid wastes -A case study. Pollution Research, Enviro Media, 10, 111-116.

Kumaraswamy N., Subramanyan B. \& Kotaiah B. (2000), Movement of groundwater pollution in and around a solid waste disposal site- a case study, Indian Journal of Environmental Protection, 20, 206-208.

Lee G.F. (2002), Solid Waste Management: USA Lined Landfill Reliability, Natural Resources Forum, A United Nations Journal, New York.

Leton, T.G; \& Omotosho, O (2004). Landfill operations in the Niger delta region of Nigeria. Engineering Geology 73(1-2): 171-177.

Mor S., Ravindra K., Dahiya R.P. \& Chandra A. (2006), Leachate Characterization and Assessment of Groundwater Pollution Near Municipal Solid Waste Landfill Site, Environmental Monitoring and Assessment, 118(1-3), 435-456.

Odoemene, U.D, \& Ofodu, J. (2006) Solid wastes management in Aba Metropolis. Int. J. Adv. Acad. Res; 2:1-7.

Olaniyan M.S., Khandekar P. \& Bhide A.D. (1998), Ground Water Pollution due to Refuse leachate: A Lab Study, Indian Journal of Environmental Protection, 18(10), 748-751.

Olowe, B.M, Oluyege, J.O, \& Famurewa, O. (2015) Prevalence of waterborne diseases and microbial assessment of drinking water quality in Ado-Ekiti and its Environs, Southwestern, Nigeria. Br Microbiol Res J 12(2):113

Oluyemi E, Adekunle. A, Adenuga A \& Makinde O. (2010). Physico-chemical properties and heavy metal content of water sources in Ife North Local Government Area of Osun State, Nigeria. Researchgate journals, 4. 10.4314/ajest.v4i10.71334.

Onwordi C. T., Dan-Sulaiman S. B. (2010). Physico-chemical characterization and heavy metals of effluents from glass processing plant in Agbara Industrial Estate, Ogun, Nigeria. Archives of Applied Science Research, 2010, 2 (1) 212 217. (http://scholarsresearchlibrary.com/archive.html).

Segun A. A, Henry O. S, Adedotun T. A, Oluwatoyosi O. S, \& Biola K. B (2017). Journal of Health and Pollution 2017 7:14, 15-22

Siyanbola T.O, Ajanaku K. O, James O.O., Olugbuyiro J.A.O., \& Adekoya J. O. (2011). Physico-Chemical Characteristics of Industrial Effluents In Lagos State, Nigeria. G. J. P\&A Sc and Tech., 01 (49-54). www.gjpast.com

Sridhar, M.K.C; Adeoye, GO (2003). Organo-mineral fertilizer from urban wastes: development in Nigeria. The Nigerian Field, 68: 91-111.

Ukem, E.O. (2008). Electroni waste: a growing challenge in Nigeria. Global Journal of Pure and Applied Sciences 14(4): 459-462.

Ukpong ECU, Udo EA, \& Umoh IC (2015). Characterization of materials from Aba waste dumpsites. Int. J. Eng. Appl. Sci. 6:1-10.

Vasanthi P., Kaliappan S. \& Srinivasaraghavan R. (2008). Impact of poor solid waste management on ground water, Environmental monitoring and assessment, 143 (1-3), 227-238.

Weli V,E, \& Ogbonna, V.A (2015). An analysis of well water quality and the incidence of water borne diseases in Emohua communities, Rivers state, Nigeria. Int J Environ Pollut Res 3(2):32-41. 